\title{
The prevalence of visual disorders in Iranian students: A meta-analysis study and systematic review
}

\author{
Kambiz Keshavarz ${ }^{1}$, Parvin Angha ${ }^{2}$, Fatemeh Sayehmiri ${ }^{3}$, Kourosh Sayemiri $^{4}$, Masood Yasemi ${ }^{5}$
}

${ }^{1}$ MD, Pediatrician, Assistant Professor of Pediatrics, Social Determinants of Health Research Center, Yasuj University of Medical Sciences, Yasuj, Iran

${ }^{2}$ Social Determinants of Health Research Center, Yasuj University of Medical Sciences, Yasuj, Iran

${ }^{3} \mathrm{PhD}$, Proteomics Research Center, Shahid Beheshti University of Medical Sciences, Tehran, Iran

${ }^{4} \mathrm{PhD}$ of Biological Statistic, Research Center of Prevention of Psychosocial Disorder, Ilam University of Medical Sciences, Ilam, Iran

${ }^{5}$ MD, Poostchi Ophthalmology Research Center, Shiraz University of Medical Sciences, Shiraz, Iran

Type of article: Meta-analysis

\begin{abstract}
Background: Visual defects have dramatic effects on health, self-esteem, and educational function of students, and delayed diagnosis will cause complications, like academic failure and psychologic disorders.

Objective: The present study aimed to investigate the prevalence of ocular disorders in Iranian students in a systematic review.

Methods: We searched databases, including PubMed, SID, Magiran, Google Scholar, and Iranmedex using the following keywords in Persian and English: disorders, vision, amblyopia, refractive errors, astigmatism, student, and Iran with all the possible combinations, important, chief, and sensitive words. Search resulted in 28 articles, conducted during a period from 1996 to 2014 in Iran and their data was analyzed using meta-analysis and random effects model. Heterogeneity of studies was assessed using I2 index, and data was finally analyzed with R Software and STATA (Version 11.2).

Results: Total number of subjects in the study was $1,117,274$, aged 2 to 18 years. The prevalence of disorders related to amblyopia, refractive error, and strabismus was $8 \%, 7 \%$ and $1 \%$, respectively. The greatest amount of refractive error was related to astigmatism (19\%) followed by myopia $(17 \%)$.

Conclusion: According to the study results, the prevalence of visual disorders among Iranian students indicated the critical necessity of screening programs for prevention of visual disorders in this age group.

Keywords: Prevalence, Visual disorders, Meta-analysis, Iran
\end{abstract}

\section{Introduction}

About $75 \%$ of an individual's general information is obtained through the visual system (1). The visual system of children does not take its final evolution up to the age of 10 years and the most important factor for growth and development of this system is clear stimuli (2). If the child's eye is deprived of receiving these stimuli, for any reason, the development of the visual system will be impaired (3). Visual acuity is of great importance in children for clear vision in writing and education, especially in school training ages (1). Visual disorders have dramatic effects on health, self-esteem, and educational function of students and if diagnosed with delay, it will cause complications, like academic failure and mental difficulties for the student (4). Also, delay in diagnosis of visual difficulties can decrease the treatment success (5). Most visual disorders are preventable at an early age. Therefore, a comprehensive study of visual problems in students is of great importance. According to studies, the most common cause of visual disorders in children include refractive errors (1-11\%), amblyopia (1-5\%) and strabismus (3.8\%) (6). Unfortunately, there is no comprehensive statistical information available in Iran and only sparse data have been

\section{Corresponding author:}

Dr. Masoud Yasemi, Poostchi Ophthalmology Research Center, Department of Ophthalmology, School of Medicine, Shiraz University of Medical Sciences, Shiraz, Iran.

Tel: +989185126077, E-mail: Ophthalmology67@gmail.com

Received: December 20, 2016, Accepted: July 12, 2017, Published: October 2017

iThenticate screening: June 29, 2017, English editing: September 28, 2017, Quality control: October 02, 2017

(C) 2017 The Authors. This is an open access article under the terms of the Creative Commons Attribution-NonCommercialNoDerivs License, which permits use and distribution in any medium, provided the original work is properly cited, the use is non-commercial and no modifications or adaptations are made. 
reported from cities in national scientific sources (7). Considering the importance of research about visual problems in children and differences in the prevalence of visual disorders in different parts of Iran, the present systematic review and meta-analysis aimed to determine the prevalence of common visual disorders in Iranian students.

\section{Material and Methods}

The present systematic review and meta-analysis study was carried out in 2015, and articles published since 1996 to 2014, related to the prevalence of visual disorders in Iranian children, in Farsi and English were searched in national and foreign databases, including SID, Magiran, IranDoc, IranMedex, MedLib, PubMed, ISI, and Google Scholar. Mentioned databases were searched using the following keywords in Persian and English: disorders, vision, amblyopia, refractive errors, astigmatism, student, and Iran with all the possible combinations, important, chief, and sensitive words. Also, the titles resulted through search and references of the selected articles were used as additional search tools. All descriptive cross-sectional or group studies that had investigated the prevalence of visual disorders in Iran were considered. Articles were selected based on three steps of title, abstract and full text. Studies with insufficient information or non-descriptive cross-sectional studies, congress abstracts, studies published in other languages than English and Persian, review and meta-analysis studies, and duplicates were excluded from the analysis. For all studies, the following data were extracted: the first author, publication year, study year, study location, sample size, and mean age, sex and the prevalence of each visual disorder (Table 1). The major inclusion criteria for including various articles into this study was mentioning visual disorders and exclusion criteria of the studies from the present research were: lack of reference to the prevalence of visual disorders, unrelated studies, and low quality of articles. The researcher collected all articles related to visual disorders first and prepared a list of abstracts after finishing the search. In this step, 86 articles were listed, which mentioned "The prevalence of visual disorders in Iran". Then, each article was independently evaluated. In this step, 14 articles were eliminated because of duplication, and among a total of 72 articles, 16 articles were omitted because of low quality, and 4 because of the unavailability of the full text, and 24 articles were deleted due to differences in the types of criteria. Finally, 28 articles were appropriate to enter meta-analysis (Figure 1). A checklist of necessary information was prepared for all studies primarily evaluated. Then, a checklist containing several parts was designed, including researcher's name, publication year and place, sample size, age, visual disorders, prevalence of visual disorders, etc. Then, fundamental data needed for research entered the chart for analysis. For calculation of variance of each study, binary distribution and for combination of prevalence of visual disorders among various studies, mean weight was used. Each study was weighed proportional to the reverse of its variance. With attention to the great difference in the prevalence among different studies (heterogeneity of studies) and significance of Heterogeneity index (I2), Random Effects Model was used in the meta-analysis. And finally, the data was analyzed by R Software and STATA (Version 11.2). The level of significance ( $\mathrm{P}$ value) was considered less than $5 \%$.

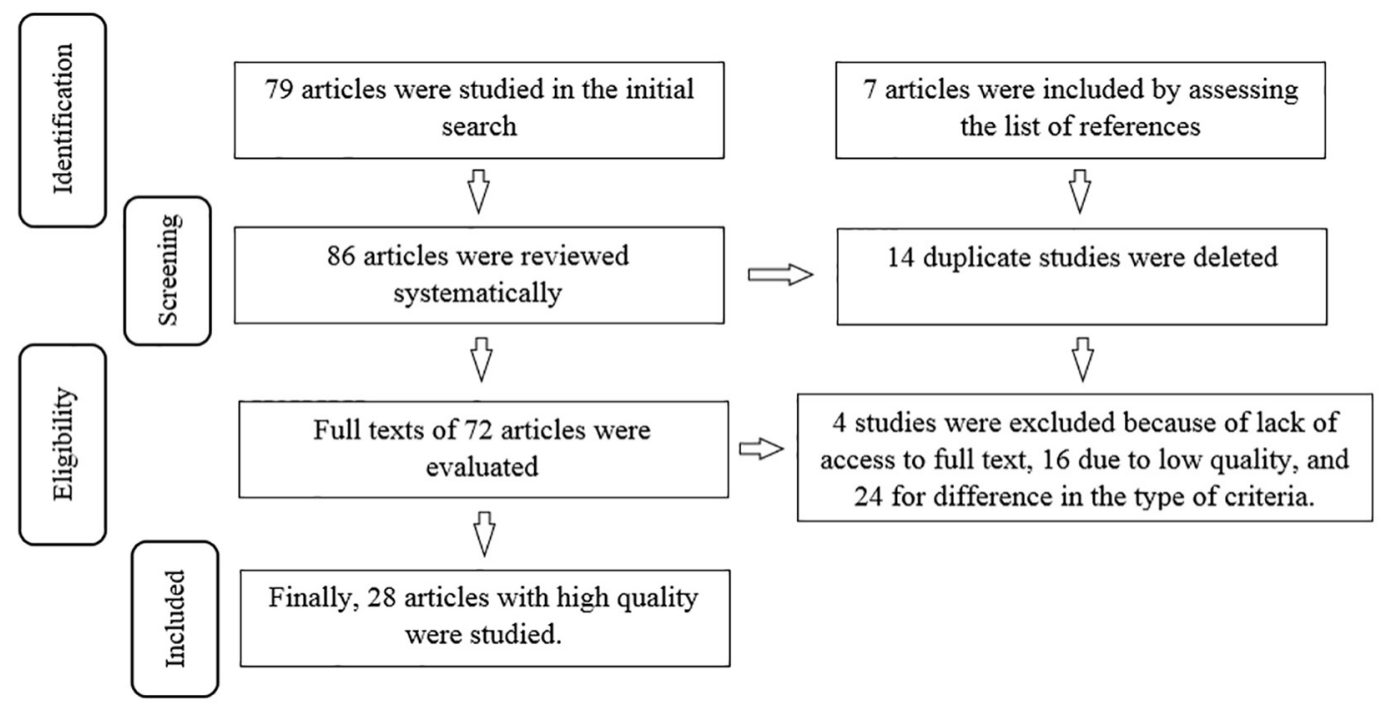

Figure 1. Flowchart of the stages of the systematic review and meta-analysis 
Table 1. General information of studies included in the meta-analysis

\begin{tabular}{|l|l|l|l|l|l|l|l|}
\hline $\begin{array}{l}\text { Ref. } \\
\text { no. }\end{array}$ & $\begin{array}{l}\text { Publication } \\
\text { year }\end{array}$ & Study year & $\begin{array}{l}\text { Age of cases } \\
\text { (year) }\end{array}$ & Male (n) & Female (n) & n (total) & City \\
\hline 9 & 2014 & 2013 & $3-6$ & & & 1,126 & Bojnoord \\
\hline 6 & 2006 & 2000 & $7-12$ & 2,348 & 2,185 & 4,533 & Kermanshah \\
\hline 11 & 2009 & $2005-2006$ & $14-18$ & 216 & & 216 & Tehran \\
\hline 12 & 2004 & $1999-2000$ & $3-6$ & & & 8,427 & Ardebil \\
\hline 28 & 2008 & 2006 & & 1,208 & 942 & 2,510 & Mashhad \\
\hline 13 & 2010 & 2004 & $11-17$ & 3,635 & 913 & 4,548 & Ardebil \\
\hline 14 & 2007 & 2004 & 6 & 436 & 379 & 815 & Shahrood \\
\hline 8 & 2009 & 2007 & $7-18$ & & & 957,582 & Iran \\
\hline 2 & 1999 & 1996 & 7 & & & 2,000 & Shahrekord \\
\hline 3 & 2014 & $2011-2012$ & $2-6$ & 8,297 & 8,302 & 16,599 & Bandar Abbas \\
\hline 15 & 2016 & 2012 & $2-6$ & 1,160 & & 75,173 & Ardebil \\
\hline 16 & 2012 & 2011 & $7-15$ & & & 1,551 & Bojnourd \\
\hline 17 & & 2010 & $14-18$ & & & 1,133 & Varamin \\
\hline 18 & 2014 & & & 5,641 & 6,180 & 11,821 & Qazvin \\
\hline 19 & 2010 & 2008 & $<15$ & 1,191 & 1,941 & 3,132 & Mashhad \\
\hline 20 & 2015 & 2012 & $7-12$ & & & 320 & Zahedan \\
\hline 21 & 2013 & 2010 & $7-14$ & 643 & 898 & 1,551 & Bojnourd \\
\hline 22 & 2016 & 2013 & & 2,127 & & 4,106 & Iran \\
\hline 23 & 1996 & & $7-8$ & 951 & 775 & 1,726 & Kerman \\
\hline 24 & 2007 & & $12-16$ & & & 1,830 & Mashhad \\
\hline 25 & 1997 & 1996 & $7-12$ & & & 1,275 & Zanjan \\
\hline 26 & 2007 & $2004-2005$ & $7-15$ & & & 3,673 & Dezful \\
\hline 26 & 2007 & $2004-2005$ & $14-18$ & & & 1,871 & Dezful \\
\hline 27 & 2014 & & $14-21$ & 212 & 222 & 434 & Aligoudarz \\
\hline 28 & 2008 & $2006-2007$ & $7-15$ & & & 1,163 & Mashhad \\
\hline 28 & 2008 & $2006-2007$ & $14-18$ & & & 947 & Mashhad \\
\hline 29 & 2015 & $2013-2014$ & $6-15$ & 631 & 520 & 1,151 & Dezful \\
\hline 30 & 2010 & $2008-2009$ & $7-15$ & 1,002 & 870 & 1,872 & Shiraz \\
\hline
\end{tabular}

\section{Results}

Basic information of studies that entered meta-analysis, including the author's name, year of publication, study place, the sample size, based on gender and age range are shown in Table 1 . The total number of subjects was $1,117,274$, in the age range of 2 to 18 years old. The raw data on prevalence of ocular disorders in different studies are demonstrated in Table 2. In Figure 2, the prevalence of strabismus in Iranian students is shown based on the random effects model. In this graph, the resultant prevalence of strabismus was 1\% (CI 95\%: 1-2\%). In Figure 3, the total prevalence of refractive errors in Iranian students is shown based on the random effects model. It has been shown that the prevalence of refractive errors was an estimated 7\% (CI 95\%: 5-9\%). Moreover, the prevalence of amblyopia in Iranian students was 8\% based on random effects model (Figure 3) (CI 95\%: 7-10\%). The overall prevalence of visual disorders has been shown in Table 3. Based on the results of this study, the overall prevalence of visual disorders in Iranian students was 5\% (Table 3), in which the prevalence of amblyopia was 8\% [Girl 2\% (CI 95\%: 1-3\%), boy 1\% (95\% confidence interval: 1-2\%)], refractive error was 7\% [Girl 8\% (CI 95\%: 6-10\%), boy 6\% (95\% confidence interval: $4-7 \%$ )], and the prevalence of strabismus was an estimated $1 \%$ (Table 3 ). The prevalence of amblyopia in Iranian students, based on random-effects model was shown in the Figure 4 . The greatest amount of astigmatism-related refractive error was $19 \%$ [girls 27\% (CI 95\%: 6-61\%) and boys $28 \%$ (CI 95\%: 5-51\%)], followed by myopia with a prevalence of $17 \%$ (Table 3). Details of the prevalence of refractive errors are shown in Table 3. 
Table 2. Prevalence of ocular disorders in studies included in the meta-analysis

\begin{tabular}{|c|c|c|c|c|c|c|c|c|c|c|c|c|c|c|}
\hline $\begin{array}{l}\text { Ref. } \\
\text { no. }\end{array}$ & $\begin{array}{l}\text { Astigmat. } \\
\text { Prev. }\end{array}$ & $\begin{array}{l}\text { Estrab. } \\
\text { Prev. }\end{array}$ & $\begin{array}{l}\text { Ref. } \\
\text { Eror } \\
\text { Prev. }\end{array}$ & $\begin{array}{l}\text { Amb. } \\
\text { prev. }\end{array}$ & $\begin{array}{l}\text { Total } \\
\text { prev. }\end{array}$ & Anisometropia & $\begin{array}{l}\text { Hyperopia } \\
\text { Prev. }\end{array}$ & $\begin{array}{l}\text { Myopia } \\
\text { Prev. }\end{array}$ & $\begin{array}{l}\text { Astigmat. } \\
\text { Prev. } \\
\text { Boys }\end{array}$ & $\begin{array}{l}\text { Astigmat. } \\
\text { Prev. } \\
\text { female }\end{array}$ & \begin{tabular}{|l|} 
Refractive \\
Eror Prev. \\
male
\end{tabular} & $\begin{array}{l}\text { Refractive } \\
\text { Eror Prev. } \\
\text { female }\end{array}$ & $\begin{array}{l}\text { Amblyopia } \\
\text { prev. male }\end{array}$ & $\begin{array}{l}\text { Amblyopia } \\
\text { prev. } \\
\text { female }\end{array}$ \\
\hline 9 & & 1.8 & 4.61 & 11.8 & & & & & & & 2.66 & 1.9 & 6.21 & 5.59 \\
\hline 6 & 1.78 & & 5 & 0.33 & 5.7 & & 0.61 & 2.6 & 1 & 0.8 & & & 0.21 & 0.45 \\
\hline 11 & 21.3 & 17.1 & & & & & & & & & & & & \\
\hline 12 & & 0.55 & 3.59 & 1.25 & 7.21 & & & & & & & & & \\
\hline 28 & 11 & 3.1 & & 1.9 & & 30.6 & & & & & & & 1.7 & 2.1 \\
\hline 13 & 27 & 0.9 & 11.4 & 2.63 & 2.63 & 59 & 17 & & & & & & 2.8 & 1.9 \\
\hline 14 & & & & & 6.4 & & & & & & & & & \\
\hline 8 & & & & & 4.6 & & & & & & & & & \\
\hline 2 & & 0.55 & & 9.9 & 2.55 & 1.5 & & & & & & & 12.5 & 14.8 \\
\hline 3 & & 0.27 & 2.72 & 1.01 & & & & & & & & & & \\
\hline 15 & & 0.34 & 0.074 & 0.14 & & & & & & & & & 0.17 & 0.12 \\
\hline 16 & & 2 & & 2.3 & & & & & & & & & 2 & 2.5 \\
\hline 17 & 10.5 & 1.5 & & 2.1 & & 3.8 & 6.1 & 33.2 & & & & & & \\
\hline 18 & 8.37 & & & 6.34 & & 5.45 & 19.8 & 66.2 & 48.48 & 51.52 & & & 44.73 & 55.27 \\
\hline 19 & 15.34 & & & & & 5.84 & & & & & & & & \\
\hline 20 & 3.4 & & & & & 21.3 & 5.8 & 6.3 & 1.8 & 5 & 55.6 & 73.1 & & \\
\hline 21 & 22 & & 6.2 & & & & 18 & 40 & & & 4.8 & 7.1 & & \\
\hline 22 & 17.43 & & & & & & 6.2 & 3.04 & 15.46 & 19.54 & & & & \\
\hline 23 & & & 7.5 & 1.7 & & & & & & & 6.2 & 9.4 & 1.4 & 2 \\
\hline 24 & 5.02 & & 24.97 & & & & 4.97 & 3.77 & & & & & & \\
\hline 25 & 2.03 & 0.47 & 8.4 & 7.8 & & 1.33 & 2.1 & 3.5 & & & & & & \\
\hline 26 & 18.7 & & & & & & 16.6 & 3.4 & 18.5 & 18.9 & & & & \\
\hline 26 & 18 & & & & & & 2.1 & 33 & 18.5 & 18.9 & & & & \\
\hline 27 & 20.7 & & & & & 4.6 & 1.2 & 29.3 & 25.9 & 15.8 & & & & \\
\hline 28 & 9.8 & & & & & 3 & 87.9 & 2.4 & & & & & & \\
\hline 28 & 11.8 & & & & & 5.6 & 8.4 & 24.1 & & & & & & \\
\hline 29 & 45.3 & & & & & & 12.9 & 14.9 & 48.5 & 41.5 & & & & \\
\hline
\end{tabular}

Study

ID

Meshkat.MR (1996)

Derakhshandeh J (1997)

Aazami.A (2004)

Omidiyan.J (2006)

Bolourian AA (2007)

Maasoomi.R (2010)

Ostadi Moghaddam.H (2013)

Hamidi.A (2014)

Safari Moradabadi.A (2014)

Ojaghi.H(2016)

Overall (I-squared $=99.6 \%, p=0.000)$

NOTE: Weights are from random effects analysis

$-.27$

\begin{tabular}{ll} 
ES $(95 \% \mathrm{C})$ & $\begin{array}{l}\% \\
\text { Weight }\end{array}$ \\
\hline $0.08(0.06,0.09)$ & 9.86 \\
$0.08(0.07,0.10)$ & 9.64 \\
$0.04(0.03,0.04)$ & 10.26 \\
$0.05(0.04,0.06)$ & 10.19 \\
$0.25(0.23,0.27)$ & 9.23 \\
$0.11(0.10,0.12)$ & 10.06 \\
$0.06(0.05,0.07)$ & 9.89 \\
$0.05(0.04,0.05)$ & 10.27 \\
$0.03(0.02,0.03)$ & 10.29 \\
\hline $0.01(0.01,0.01)$ & 10.31 \\
$0.07(0.05,0.09)$ & 100.00 \\
\hline
\end{tabular}

.27

Figure 2. The prevalence of strabismus in Iranian students, based on random-effects model. 
Table 3. The prevalence of visual disorders in Iranian students; derived from meta-analysis study

\begin{tabular}{|c|c|c|c|c|c|}
\hline Visual disorder (Prevalence \%) & $\mathrm{I}^{2 \%} \%$ & p-value & Prevalence (CI 95\% & Studies & umber \\
\hline Myopia & 99.9 & 0.000 & $0.17(0.09-0.25)$ & 16 & \\
\hline Hyperopia & 99.9 & 0.000 & $0.16(0.10-0.22)$ & 17 & \\
\hline Anisometropia & 99.8 & 0.000 & $0.11(0.06-0.17)$ & 13 & \\
\hline Amblyopia & 99.8 & 0.000 & $0.08(0.07-0.10)$ & 14 & \\
\hline strabismus & 97.2 & 0.000 & $0.01(0.01-0.02)$ & 12 & \\
\hline Astigmatism & 99.9 & 0.000 & $0.19(0.06-0.32)$ & 20 & \\
\hline $\begin{array}{l}\text { Study } \\
\text { ID }\end{array}$ & & & & $\mathrm{ES}(95 \% \mathrm{CI})$ & $\begin{array}{l}\text { \% } \\
\text { Weight }\end{array}$ \\
\hline Meshkat.MR (1996) & & 8 & & $0.02(0.01,0.02)$ & 7.20 \\
\hline Derakhshandeh J (1997) & & & $\rightarrow 0$ & $0.78(0.76,0.80)$ & 6.30 \\
\hline Salehi.A (1999) & & & & $0.10(0.09,0.11)$ & 6.93 \\
\hline Aazami.A (2004) & & i & & $0.01(0.01,0.01)$ & 7.27 \\
\hline Omidiyan.J (2006) & & i & & $0.00(0.00,0.00)$ & 7.28 \\
\hline Ostadi Moghaddam.H (2008) & & \& & & $0.02(0.01,0.02)$ & 7.22 \\
\hline Maaso omi.R (2010) & & - & & $0.03(0.02,0.03)$ & 7.24 \\
\hline Faghihi.M (2010) & & - & & $0.02(0.01,0.03)$ & 7.13 \\
\hline yekta.AA (2010) & & $*$ & & $0.03(0.02,0.04)$ & 7.20 \\
\hline Yekta.AA (2012) & & - & & $0.02(0.02,0.03)$ & 7.19 \\
\hline Hamidi.A (2014) & & & & $0.12(0.11,0.12)$ & 7.22 \\
\hline Safari Moradabadi.A (2014) & & ; & & $0.01(0.01,0.01)$ & 7.28 \\
\hline Khalaj.M (2014) & & 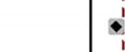 & & $0.06(0.06,0.07)$ & 7.24 \\
\hline Ojaghi.H (2016) & & & & $0.00(0.00,0.00)$ & 7.29 \\
\hline Overall $(\mathrm{I}$-squared $=99.8 \%, \mathrm{p}=0.000)$ & & 6 & & $0.08(0.07,0.10)$ & 100.00 \\
\hline \multicolumn{3}{|l|}{ NOTE: Weights are from random effects analy sis } & & & \\
\hline $\begin{array}{ll}1 \\
-.803\end{array}$ & & 0 & $\begin{array}{l}.1 \\
.803\end{array}$ & & \\
\hline
\end{tabular}

Figure 3. The prevalence of refractive errors in Iranian students, based on random-effects model.

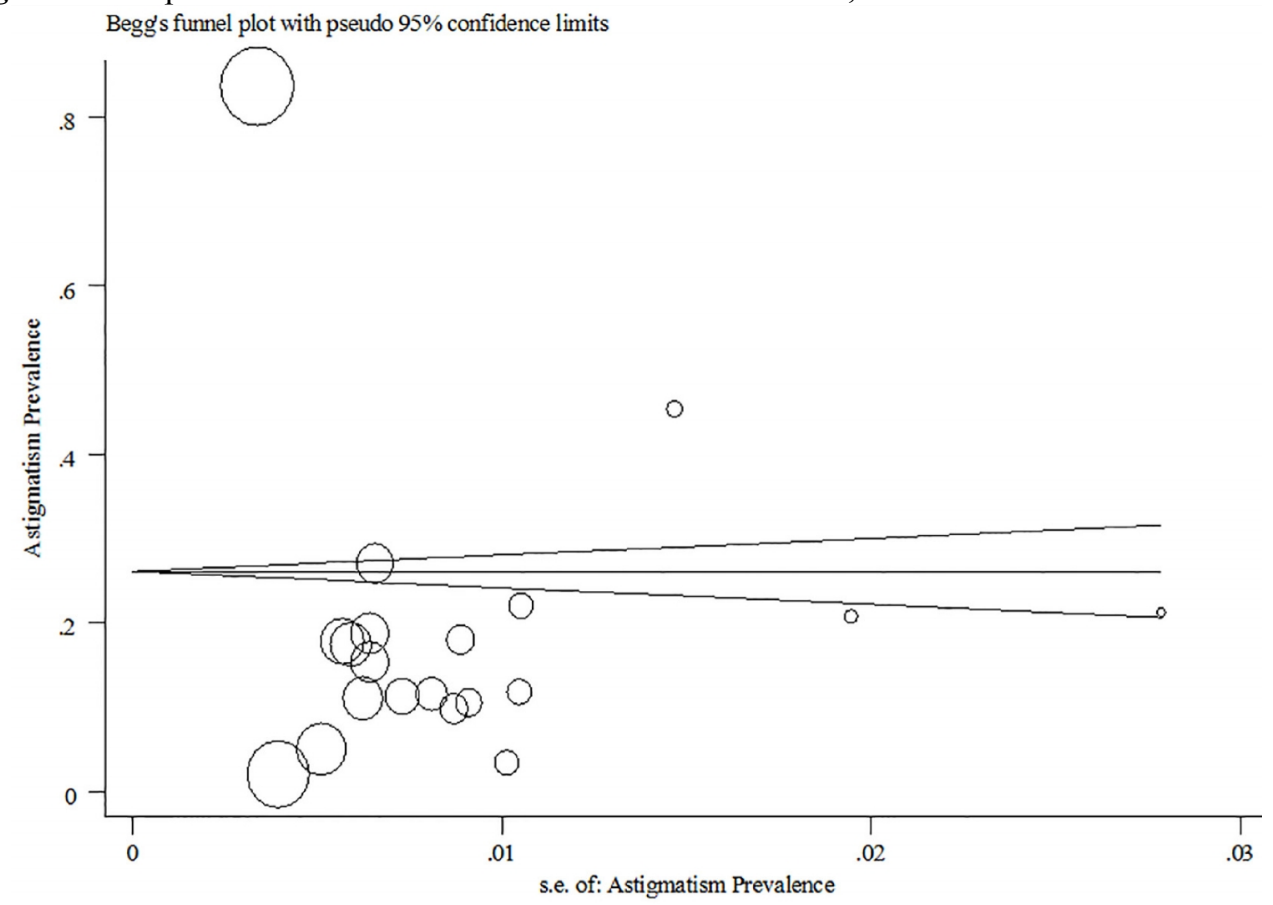

Figure 4. The prevalence of amblyopia in Iranian students, based on random-effects model. 


\section{Discussion}

One of the goals of the WHO (world health organization) is to prevent visual disorders in children by the year 2020 (31). According to studies, visual disorders, especially refractive errors, strabismus and amblyopia are higher in students than in other groups (34-36). Amblyopia occurs in the first decade of life and if diagnosed at this age, it can be treated, and prevention of further development can be done by appropriate treatment measures (32, 33). In the present study, the prevalence of amblyopia among Iranian students was $8 \%$, while based on similar studies in developed countries, the prevalence of amblyopia in preschool children has been reported as 1-5\% (48-50). The overall prevalence of visual disorders, including amblyopia, strabismus, refractive errors and other ocular diseases in children, was $2.4-6.1 \%$ in various articles (51). In the present study, the prevalence of visual disorders in students was 5\%, which was higher compared with many developed countries (37-41). Of course, differences in the various reports could be due to taking into account the different diagnostic criteria, different characteristics of the study population, and skills and expertise of the examiners $(2,52-60)$. In the present study, the prevalence of strabismus was $1 \%$, which is consistent with the findings of previous studies, however differences in the prevalence of different types of strabismus (phoria or tropia, exo, or eso) are likely, but given that in most of the selected studies, the type of strabismus was not specified, it was not possible to compare the prevalence of different types. The overall prevalence of strabismus in studies conducted in different parts vary from 0.5 to $2 \%(2,16,17)$. Another common cause of visual disorders among this age group was refractive errors, which was $7 \%$ in the present study. Numerous studies are conducted worldwide in the field of refractive errors in the age groups at risk, including children and students, and prevalence of these disorders are highly variable in different regions (17-24, 26-29). According to most studies conducted in the world, myopia is introduced as the most common refractive error among students (63, 64). Also, in some comprehensive studies out of Iran, the prevalence of myopia has been reported higher than hyperopia (65). This difference in the prevalence needs to be confirmed by further studies.

\section{Conclusions}

Various reports have questioned screening for visual disorders in Iran, and on the basis of these studies (64, 65), these programs are not sensitive enough to detect and refer patients to seek appropriate treatment, on the other hand, given that most parents rely on the results of these examinations, and do not pay attention to the possible complaints of their children, identification of these disorders are delayed and their treatment becomes more difficult (43, 44). Therefore, it is suggested to increase the awareness of parents, use highly-experienced staff in screening programs, and increase the validity and sensitivity of the examinations by more professional methods.

\section{Acknowledgments:}

The authors thank research part of Ilam and Yasuj University of Medical Sciences. None of the authors has conflict of interest with the submission.

\section{Conflict of Interest:}

There is no conflict of interest to be declared.

\section{Authors' contributions:}

All authors contributed to this project and article equally. All authors read and approved the final manuscript.

\section{References:}

1) Shirzadeh E, KhosroAbadi A. Study of Visual Acuity and Comparison of Snellen Chart and Retinoscopy in Diagnosis of Refractive Errors. Armaghane danesh. 2005; 10(37): 1-7.

2) Salehi A, Lotfizadeh M. Prevalence of Amblyopia in 2000 first year student in primary school Kord spring and summer of 1375. Jornal of University of Medical Science. 1999; 1: 53-46.

3) Safari Moradabadi A, Ghanbarnejad A, Bani-Hashemi A, Taghi Pourshoorijeh L, Tofighi M, Zamzam T, et al. Amblyopia screening in children in Bandar Abbas (Iran) during 2011-2012. Electron physician. 2014; 6(3): 906-11. doi: 10.14661/2014.906-911. PMID: 25763166, PMCID: PMC4324288.

4) Marotz LR. Health Safety and Nutrition for the Young Child. 8th ed. An International Thomson Publishing Co. 2012: 341-9.

5) Ouji N, Pasalar M, Fazel M, Nekui F, Ouji N. The evaluation of common visual disorders in primary school children in Fasa; 1999-2000. Armaqan e Danesh. 2004; 9(36): 17-24.

6) Omidian J, Pourbiazar MR, Sheikhi F, Ansari MR, Daneshgar F, Ghaderi E. Visual Disorders Prevalence in Primary School Children in Kermanshah (2001). J Kermanshah Univ Med Sci. 2006; 10(2): 168-76. 
7) Merat H. Prevalence of amblyopia in school age children ib Qazvin. J Qazvin Univ of Med Sc. 2002; 1(21): 54-8.

8) Amirkhani MA, Ziaedini SH, Dashti M, Aminaei T, Mir Moghtaei P, Ardalan G, et al. Prevalence of visual impairments among school-aged children: the results of a national screening program. IUMS. 2010; 27(101): 717-23.

9) Hamidi A, Jalalifar S, Yaghubi M, Akaberi A, Ghuparanlu M, Shojaei Sh. The prevalence of amblyopia in children aged 3 to 6 years old in bojnourd in 1392. NKUMS. 2014; 6(3): 565-72.

10) Xiao O, Morgan IG, Ellwein LB, Mingguang H. Prevalence of Amblyopia in School-Aged Children and Variations by Age, Gender, and Ethnicity in a Multi-Country Refractive Error Study. Ophthalmology. 2015; 122(9): 1924-31. PMID: 26278861.

11) Ghorbani Birgani AR, Mahfoozpour S, Farzin Fard F, Akbarzadeh Baghban AR. The most common vision and hearing disorders among high school students 14-18 years old martyr Beheshti University of Medical Sciences in Tehran in areas covered by 85. 2007; 3(4): 174-80.

12) Aazami A, Ojaghi H, Sadegiyeh S. Result of Amblyopia screening in Ardabil province 1998- 2001. J Ardabil Univ Med Sci. 2003; 10(3): 10-6.

13) Masumi R, Ojaghi H, Masumi N, Jafarzadeh S. Prevalence and Causes of Amblyopia among Middle School Students in Ardabil City During 2004. J Ardabil Univ Med Sci. 2010; 11(1): 67-75.

14) Jamali P, Fotouhi A, Hashemi H, Younesian M, Jafari A. Refractive errors and amblyopia in children entering school: Shahrood, Iran. Optom Vis Sci. 2009; 86(4): 364-9. doi: 10.1097/OPX.0b013e3181993f42. PMID: 19289975.

15) Ojaghi H, Moghaddar R, Ahari SS, Bahadoram M, Amani F. Amblyopia prevention screening program in Northwest Iran (Ardabil). Int J Prev Med. 2016; 7: 45. doi: 10.4103/2008-7802.177887. PMID: 27076883, PMCID: PMC4809124.

16) Yekta AA, Hashemi H, Azizi E, etal.The prevalence of amblyopia and strabismus amon gschool children in Northeastern Iran,2011. Iran J ophthalmol. 2012; 24: 3-10.

17) Faghihi M, Ostadi Moghaddam H, Fatemi A, Heravian J, Yekta A. The Prevalence of refractive errors, strabismus and amblyopia in schoolboys of Varamin, Iran, in 2010. Iran J ophthalmol. 2012; 24: 33-9.

18) Khalaj M, Aghazadeh Amiri M, Mohammadi Zeidi I, Khosravi B, Mohammadi Nia M, Keshtkar A. Refractive Errors in School-age Children in Qazvin, Iran. Biotech Health Sci. 2014; 1(2): e22087. doi: $10.17795 /$ bhs-22087.

19) Ostadimoghaddam H, Fotouhi A, Hashemi H, Yekta A, Heravian J, Rezvan F, et al. Prevalence of the refractive errors by age and gender in Mashhad, Iran: the Mashhad eye study. Clin Experiment Ophthalmol. 2011; 39(8): 743-51. doi: 10.1111/j.1442-9071.2011.02584.x. PMID: 21631683.

20) Mahjoob M, Heydarian S, Nejati J, Ansari-Moghaddam AR, Ravandeh N. Prevalence of refractive errors among primary school children in a tropical area, South eastern Iran. Asian Pac J Trop Biomed. 2016; 6(2): 181-4. doi: 10.1016/j.apjtb.2015.10.008.

21) Ostadimoghaddam H, Yekta AA, Hashemi H, Heravian J, Derakhshan A, Azizi E, et al. Prevalence of Uncorrected Refractive Errors in School children; A Crucial Vision Screening to Consider! Iran J ophthalmol. 2013; 25(1): 59-65.

22) Hasshemi H, Yekta AA, Jafarzadehpur E, Ostadimoghaddam H, Etemad K, Asharlous A, et al. High Prevalence of Refractive Errors in 7 Year Old Children in Iran. Iran J Public Health. 2016; 45(2): 194-202. PMID: 27114984, PMCID: PMC4841874.

23) Meshkat MR, Nikian Y, Sanjari S. Prevalence of Amblyopia in 7-8 Year Old Students of Primary Schools of Kerman City During the Year 1996. J Kerman Uni Med Sci. 1997; 4(3): 132-5.

24) Bolourian AA, Safariyan L, Shayegan MR, Zareh H. Epidemiology The prevalence of refractive errors in the 16-12 year-old school students in the city of Mashhad. Journal of Mashhad University of medical sciences. 2007; 3(9): 11-4.

25) Derakhshandeh J, Mosavinasab D. Prevalence and type of refractive school children in Zanjan. ZUMS J. $1997 ; 21$.

26) Fotouhi A, Hashemi H, Khabazkhoob M, Mohammad K. The prevalence of refractive errors among schoolchildren in Dezful, Iran. Br J Ophthalmol. 2007; 91(3): 287-92. doi: 10.1136/bjo.2006.099937. PMID: 17035280, PMCID: PMC1857661.

27) Hashemi H, Rezvan F, Ostadimoghaddam H, Abdollahi M, Hashemi M, Khabazkhoob M. High prevalence of refractive errors in a rural population: 'Nooravaran Salamat' Mobile Eye Clinic experience. Clin Exp Ophthalmol, 2013; 41(7): 635-43. doi: 10.1111/ceo.12071. PMID: 23331326. 
28) Ostadimoghadam H, Fotouhi A, Khabazkhoob M, Heravian J, Yekta AA. Prevalence and Risk Factors of Refractive Errors among schoolchildren in Mashhad, 2006-2007. J Curr Ophthalmol. 2008; 20(3): 3-9.

29) Norouzirada R, Hashemib H, Yektac AA, Nirouzada F, Ostadimoghaddamd H, Yazdanic N, et al. The prevalence of refractive errors in 6- to 15-year-old schoolchildren in Dezful, Iran. J Curr Ophthalmol. 2015; 27(1-2): 51-5. doi: 10.1016/j.joco.2015.09.008. PMID: 27239576, PMCID: PMC4877718.

30) Yekta A, Fotouhi A, Hashemi H, Dehghani C, Ostadimoghaddam H, Heravian J, et al. The prevalence of anisometropia, amblyopia and strabismus in schoolchildren of Shiraz, Iran. Strabismus. 2010; 18(3): 10410. doi: 10.3109/09273972.2010.502957. PMID: 20843187.

31) World Health Organization. International Statistical Classification of Diseases and Related Health Problems. 10 th Rev ed. Washington DC: Am J Psychiatry, Inc; 1992: 456-70.

32) Del Monte MA, Greenward MJ, Mets MB, Wilson ME, Wright KW. Pediatric ophthalmology and strabismus. Sediatrico. American Academy of ophthalmology. 1995; 259-65.

33) Greenwald MJ, Paeks MM. Duane's clinical ophthalmology. Revised ed. Philadelphia: JB Leppincott Company; 1994. Amblyopia.

34) Das M, Spowart K, Crossley S, Dutton GN. Evidence that children with special needs all require visual assessment. Arch Dis Child. 2010; 95: 888e92. doi: 10.1136/adc.2009.159053. PMID: 20647259.

35) Woodhouse JM, Davies N, McAvinchey A, Ryan B. Ocular and visual status among children in special schools in Wales: the burden of unrecognised visual impairment. Arch Dis Child. 2014; 99: 500e4. doi: 10.1136/archdischild-2013-304866. PMID: 24281359.

36) Chang YS, Shih MH, Tseng SH, Cheng HC, Teng CL. Ophthalmologic abnormalities in high school students with mental retardation in Taiwan. J Formos Med Assoc. 2005; 104: 578-84. PMID: 16193179.

37) Tasman W, Jaeger EA. Patients with amblyopia and strabismus. In: Clinical Ophthalmology. Philadelphia, Pa: Lippincott Williams \& Wilkins; 2000: 119-24.

38) Abolfotooh MA, Badawi I, Faheem Y. Prevalence of amblyopia among schoolboys in Abhacity, Asir resion Saudia Arabia. J Egypt Public Health Assoc. 1994; 69(1-2): 19-30.

39) Snawdan L. Prevalence of Amblyopia in 1550 students with 10-18 years old in Rovanda. Ophtalmol Scand. 1999; 53(2): 378-82.

40) Faghihi M, Ostadimoghaddam H, Yekta AA. Amblyopia and strabismus in Iranian schoolchildren, Mashhad. Strabismus. 2011; 19(4): 147-52. PMID: 22107119.

41) Chia A, Dirani M, Chan YH. Prevalence of amblyopia and strabismus in young singaporean chinese children. Invest Ophthalmol Vis Sci. 2010; 51(7): 3411-7. doi: 10.1167/iovs.09-4461. PMID: 20207979, PMCID: PMC397.9488

42) Al Faran MF. Prevalence of ocular disorders among schoolboys in five villages in Al-Baha region. Ann Saudi Med. 1992; 12(1): 3-7. PMID: 17589123.

43) Khabazhkoob M, Hashemi H, Mehrabi Y, Eshrati B, Etemad K, Soori H. Validity of vision screening in school children of Iran. JPSR. 2014; 3(2): 51-61.

44) Khandast R, Noa P, Arabi A. Evaluation of 'vision screening' program for three to six-year-old children in the Republic of Iran. Indian J Ophthalmol. 2009; 57: 437-42. doi: 10.4103/0301-4738.57151. PMID: 19861745, PMCID: PMC2812762.

45) Cordonnier M, de Maertelaer V. Screening for amblyogenic factors in preschool children with the retinomax hand-held refractor: do positive children have amblyopia and is treatment efficacious? Strabismus. 2005; 13: 27-32. doi: 10.1080/09273970590901829.

46) Greenberg AE, Mohney BG, Diehl NN, Burke JP. Incidence and types of childhood esotropia: a population-based study. Ophthalmology. 2007; 114: 170-4. doi: 10.1016/j.ophtha.2006.05.072. PMID: 17070595.

47) Richardson SR, Wright CM, Hrisos S, Buck D, Clarke MP. Stereoacuity in unilateral visual impairment detected at preschool screening: outcomes from a randomized controlled trial. Invest Ophthalmol Vis Sci. 2005; 46: 150-4. doi: 10.1167/iovs.04-0672. PMID: 15623768.

48) Govindan M, Mohney BG, Diehl NN, Burke JP. Incidence and types of childhood exotropia: a populationbased study. Ophthalmology. 2005; 112: 104-8. doi: 10.1016/j.ophtha.2004.07.033. PMID: 15629828.

49) Jensen H, Gold Schmidt E. Visual acuity in Danish school children. Acta Ophthalmol. 1986; 64: 187. doi: 10.1111/j.1755-3768.1986.tb06898.x.

50) Vereecken E, Feron A, Evens . Importance de la detection precoce du strabism et al de Iamblyopie. Bull Soc Belge Ophalmol. 1966; 142: 729.

51) Snowdon SK, Stewart-Brown SL. Preschool Vision Screening. Health Technol Assess. 1997; 1(8): 1-83. 
52) Smith LK, Thompson JR, Woodruff G, Hiscox F. Social deprivation and age at presentation in amblyopia. J Public Health Med. 1994; 16: 348-51. PMID: 7999389.

53) Tasman W. Duane's Clinical Ophthalmology, Revised ed. Philadelphia: Lippincott Co; 1991.

54) Yazawa K, Suga J, Wakita S, Sumitomo M, Uemura Y. The Tokyo Metropolitan Home Vision Screening Program for amblyopia in 3-year-old children. Am J Ophthalmol. 1992; 114: 416-9. doi: 10.1016/S00029394(14)71851-3.

55) Lithander J. Prevalence of amblyopia with anisometropia or strabismus among school children in the Sultanate of Oman. Acta Ophthalmol Scand. 1998; 76: 658-62. PMID: 9881546.

56) Williamson TH, Andrews R, Dutton GN, Murray G, Graham N. Assessment of an inner city visual screening programme for preschool children. $\mathrm{Br} \mathrm{J}$ Ophthalmol. 1995; 79: 1068-73. doi: 10.1136/bjo.79.12.1068. PMID: 8562537, PMCID: PMC505342.

57) Von Nordeen GK, Campo EC. Binocular vision and ocular motility. USA: CV Mosby; 1990.

58) Moradabadi AS, Ghanbarnejad A, Bani-Hashemi A, Pourshoorijeh LT, Tofighi M, Zamzam T, et al. Amblyopia screening in children in Bandar Abbas (Iran) during 2011-2012. Electron physician. 2014; 6(3): 906-11. doi: 10.14661/2014.906-911. PMID: 25763166, PMCID: PMC4324288.

59) Webber AL, Wood J. Amblyopia: prevalence, natural history, functional effects and treatment. Clin Exp Optom. 2005; 88: 365-75. doi: 10.1111/j.1444-0938.2005.tb05102.x. PMID: 16329744.

60) Matsuo T, Matsuo C. The prevalence of strabismusand amblyopia in Japanese elementary school children. Ophthalmic Epidemiol. 2005; 12: 31-6. doi: 10.1080/09286580490907805. PMID: 15848918.

61) Hashemi H, lribarren R, Morgan IG, Khabazkhoob M, Mohammad K, Fotohi A. Increasesd hyperopia with ageing based on cycloplegic refractions in adults: the Tehran Eye Study. Br J Ophthalmol. 2009; 94(1): 203. doi: 10.1136/bjo.2009.160465.

62) Read SA, Collins MJ, Carmey LG. A review of astigmatism and its possible genesis. Clin Exp Option. 2007; 90: 5-19. doi: 10.1111/j.1444-0938.2007.00112.x. PMID: 17177660.

63) Yared AW, Belaynew W, Destaye Sh, Ayanaw T, Zelalem E. Prevalence of Refractive Errors Among School Children in Gondar Town, Northwest Ethiopia. Middle East Afr J Ophthalmol. 2012; 19(4): 372376. PMID: 23248538.

64) Kedir J, Girma A. Prevalence of Refractive Error and Visual Impairment Among Rural School-Age Children of Goro District, Gurage Zone, Ethiopia. Ethiop J Health Sci. 2014; 24(4): 353-8. PMID: 25489200.

65) Fotouhi A, KhabazKhoob M, Hashemi H, Yekta A, Mohammad K . Importance of Including Refractive Error Tests in School Children's Vision Screening. Arch Iran Med. 2011; 14(4): 250-3. doi: 0011144/AIM.005. PMID: 21726100. 